\title{
MEMS 光可変減衰器のためのデバイス実装技術
}

\author{
諫本 圭史 ${ }^{*}$, 鄭 昌鎬 ${ }^{*}$, 藤田 博之 ${ }^{* *}$, 年吉 洋 ${ }^{* *}$
}

\section{MEMS Assembly Technology for Variable Optical Attenuator}

Keiji ISAMOTO* , Changho CHONG* , Hiroyuki FUJITA** and Hiroshi TOSHIYOSHI ${ }^{* *}$

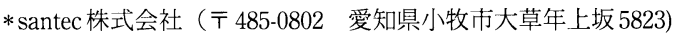

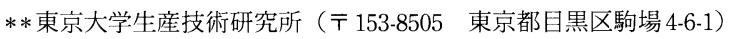 \\ *Santec Corporation (5823 Nenjozaka, Ohkusa, Komaki-shi, Aichi 485-0802) \\ **Institute of Industrial Science, the University of Tokyo (4-6-1 Komaba, Meguro-ku, Tokyo 153-8505)
}

\section{1. はじめに}

Micro-Electro-Mechanical-Systems (MEMS) 産業の近年の 成長は目覚しく, 幅広い分野で本格的な実用化の時代を迎 えつつある。なかでも光 MEMS 製品はMEMS の特徽を最も 活かしたアプリケーションのひとつで，テキサス・インス ツルメンツ社製の $\mathrm{DMD}^{1)}$ などはその代表的な成功例といえ る。

光通信への MEMS 技術の本格的な応用はLucent社のラ ムダルータ ${ }^{2)}$ に代表される大規模光クロスコネクトスイッ チの開発をきっかけに始まった。2000年の通信バブル崩壊 とともに大規模光クロスコネクトスイッチの開発は下火と なったが, MEMSの特徴（小型，高精度，量産性が高いな ど）を活かした光デバイスとして, 本稿で紹介する光可変 減衰器 (Variable Optical Attenuator: VOA) だけでなく, 光ス イッチ, チューナブルフィルタなどの開発はその後も継続 された。市場環境の非常に厳しい期間が続いたが，それら の MEMS を用いた光通信用デバイスはその多くが実用化さ れてきた。

MEMSの実用化に際しては，デバイスそのものの開発だ けでなく実装技術も非常に重要となる。MEMSの実装は小 型デバイスのハンドリングといった側面だけでなく，実装 に伴う応力の緩和や温度依存性の低減など性能面からの要 求も多い。そのため, 実装技術の開発がデバイス開発以上 に難航し，実用化のボトルネックとなっている。われわれ が開発を進めたVOA でも，デバイス実装についてはさまざ まな工夫を施して改善に取り組んだ。本稿ではわれわれが 開発したMEMS-VOAの概要とあわせて, VOA用途で特に 重要となるデバイスの安定性に着目した実装技術について 紹介する。

\section{VOAの基本構成}

\subsection{VOAの概要}

Fig. 1 に光通信ネットワークの概要とVOA の使用例を示 す。VOA とはファイバ中の光の強度を調整するためのコン ポーネントであり，デバイスのダイナミックレンジに合わ せて光量を減衰させるために使われる。Fig. 1のとおり受 光素子や光増幅器の前, またはレーザの直後など, 光通信 ネットワークのさまざまな部分に用いられている。また, 波長多重 (Wavelength Division Multiplexer: WDM) 通信の場 合には各チャネルのレベルを調整するダイナミックゲイン イコライザの中にもVOA は用いられる。

\subsection{VOAの構成}

VOA は品質の高い通信ネットワークを維持するためには 必要不可欠な部品である。そのため, システム中に使用さ れる数量も大きく, 小型化 /低価格化は常に求められてい る。そこでわれわれは, 性能, 価格およびサイズを総合的 に考慮したうえで，Fig. 2の方式を採用した。

本方式では，2芯ファイバ，コリメータレンズおよびチ ルトミラー型の MEMSを用いる。2芯ファイバの一方から 出た光が, 折り返しの光学系を通ってもう一方のファイバ に結合するように構成する。MEMSデバイスに電圧を印加

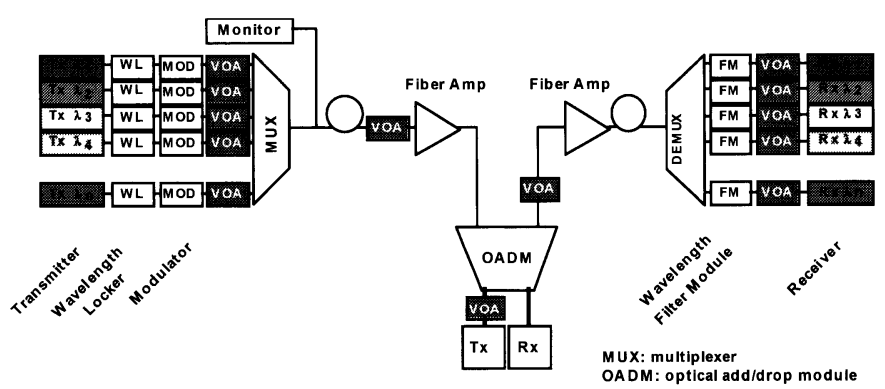

Fig. 1 VOAs in fiber optic network 


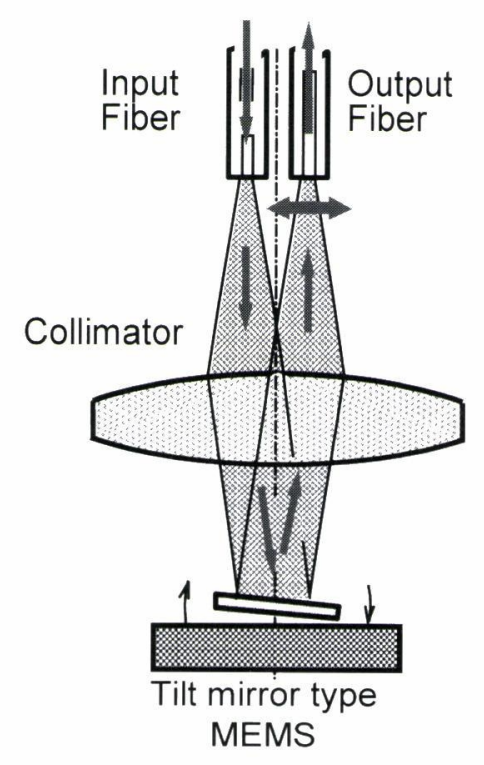

Fig. 2 Configuration of MEMS VOA

してミラーを傾けると結合損失が発生し，光量を調整する ことができる。本方式は基本構成がシンプルになることが 特徵で, 市場の要求である小型化/低価格化の実現に優位 である。また，ファイバが一方向に出せるためシステム機 器への組み込みを考えても効率的にスペースを利用できる。 多チャンネル化についても本方式の並列化により実現しや すい。

コリメータレンズは焦点距離が約 $1.8 \mathrm{~mm}$ ののを用い た。コア系が $10 \mu \mathrm{m}$ 程度のシングルモードファイバ同士の 結合のため，わずかなミラー部の角度変化でも結合損失は 大きく変化する。そのため目標とする $30 \mathrm{~dB}$ の減衰量（結 合損失）を実現するミラーの傾き角は高々 0.3 度程度とな る。最大回転角度を小さく抑えることはMEMS 設計への負 担を大幅に軽減し，安定したデバイスの実現を可能にする。 一方, 本構成は外部から与えられる衝撃や応力に対しても 敏感に反応する系となるため, 光学性能に対してはトレラ ンスが小さい構成となっている。この点については, 組み 立て時の部品固定を従来の接着剂から溶接に切り替えて安 定度の高い光学系を構築することで対策を施した。

\section{3. 非対称駆動平行平板型チルトミラーMEMSの作製}

\section{1 デバイスの基本設計}

本開発では実用化までの時間を短縮するために，デバイ 又設計の初期段階から信頼性が高く生産性に優れたMEMS の実現を心掛けた。基本的な駆動原理は, 構造も工程も簡 単な平行平板型の静電アクチュエータを採用し, 非刘称駆 動型平行平板 (ASymmetrically driven Parallel plate: ASP) 型 チルトミラーを用いることでさらに層構造を簡略化した。

Fig. 3 にASP型チルトミラーMEMSの基本構造を, Fig. 4 に作製したサンプルの写真を示す。中央に円形のミラーが ありその両端にアクチュエータが設けられている。アク

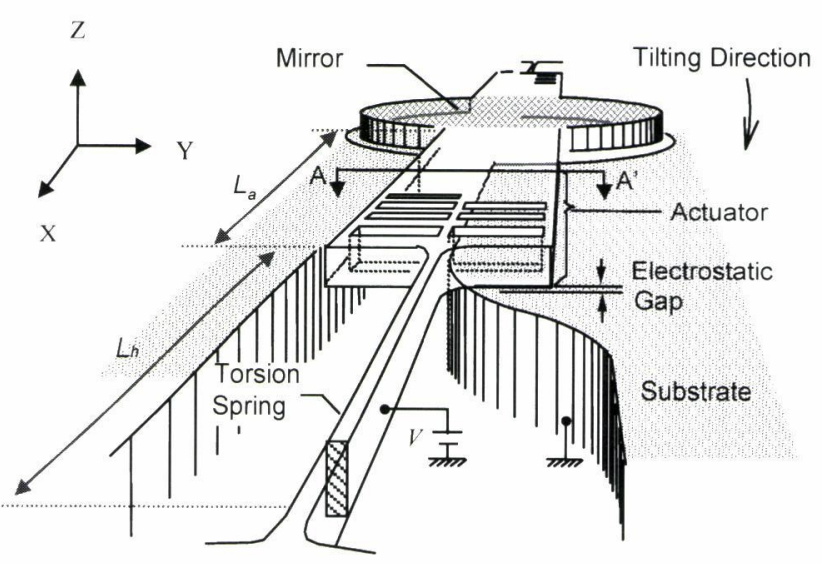

(a)

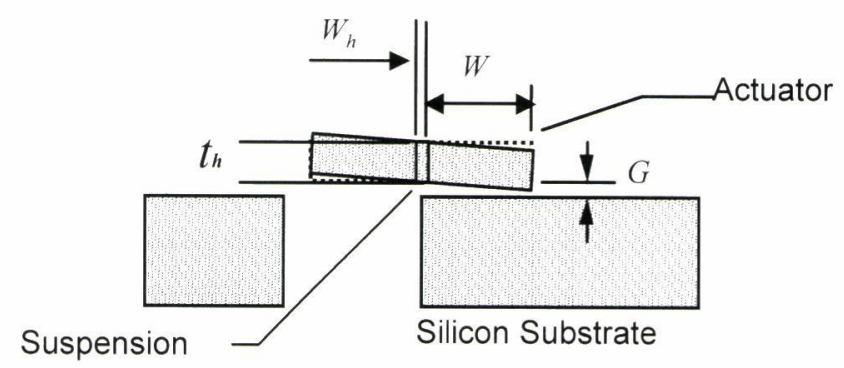

(b)

Fig. 3 Schematic diagram of ASP-type TM (a) Three dimensional view, (b) Cross section of A-A'

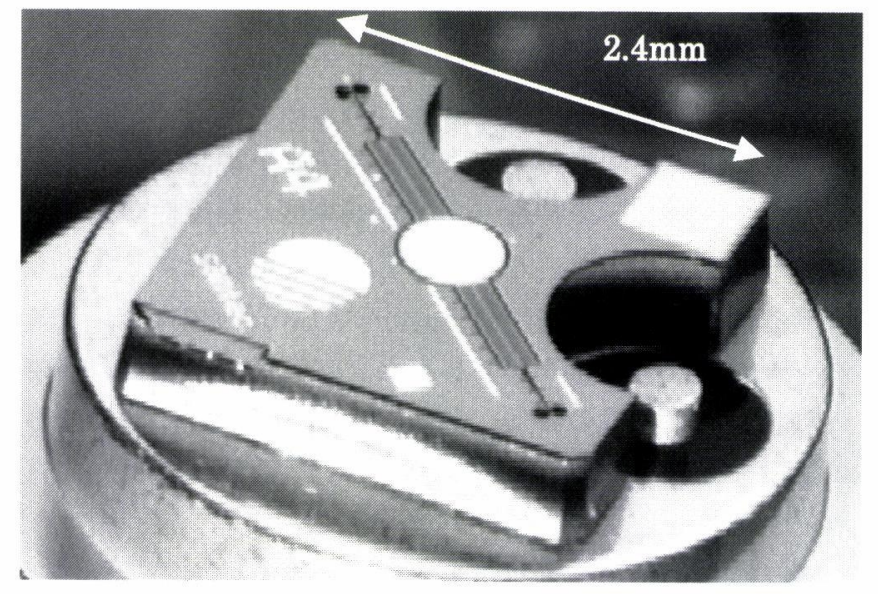

Fig. 4 Photograph of ASP-type MEMS

チュエータとミラーは一体となっておりこれを両端の トーションバーで支えている。これらの上部の構造から一 定の静電ギャップをはさんで下部電極を兼ねた基板がある。 Fig. 3(a)に示す通りアクチュエータの左半分の対向する場所 には貫通孔が設けてある。そのためアクチュエータと基板 の間に電圧を印加する之対向基板のある右側だけに引力が 発生し回転トルクが生まれる。このように基板に貫通孔を 設けて電極と基板を一体化することで, 従来のチルトミ ラーで必要であった電極層が不要となる。その結果, SOI (Silicon on Insulator) ウエハを加工するだけのバルクマイク 
1
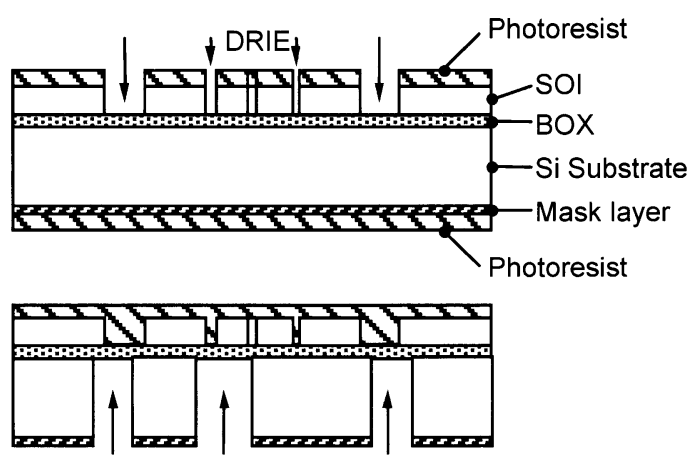

DRIE

3

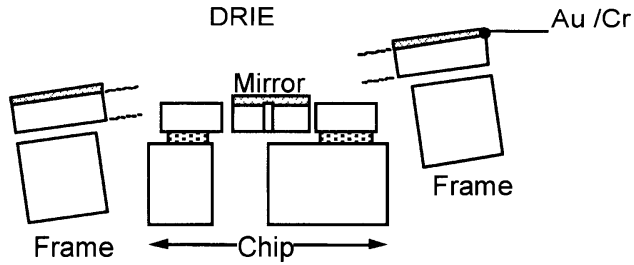

Fig. 5 Fabrication process

ロマシニングによる作製が可能となる。SOIによるバルク マイクロマシニングは，工程を簡略化するだけでなく， ミ ラーを始めとする構造体を単結晶シリコンで作製できるメ リットもある。単結晶シリコンで作製された構造体は平坦 性・平滑性の点でミラーとしても性能が高く信頼性にも優 れている。詳細設計については諫本らの報告3を参照され たい。

\section{2 製造工程}

すでに述べたとおり ASP 型MEMS はSOI ウエハを用いた バルクマイクロマシニングで作製される。工程フローの概 略図をFig. 5 に示す。主な流れは以下のとおりである。

(1) 不純物をドープしたSOI ウエハを準備する。活性層面 にフォトリソグラフィーでレジストパターンを作製し Deep Reactive Ion Etching (DRIE) でシリコン酸化膜まで高アスペ クト比のエッチングをする。

(2) (1)と同様に裏面から基板を加工する。裏面の加工は 数百 $\mu \mathrm{m}$ 程度の深堀が必要となるため, マスクにはアルミ またはシリコン酸化膜を使用する。

(3) 埋め込み酸化膜 (Buried Oxide: BOX) 層をフッ酸で犠 牲層エッチングして構造体をリリースした後, $\mathrm{Cr}-\mathrm{Au}$ をシ リコン上に成膜してミラーを作製する。

基本的に貼り合わせ基板を加工するだけであるため工程 数が少なくなり, リードタイムも短縮される。さらに, 従 来であれば成膜時に発生した膜の応力や不均一性などの弊 害も抑えることができ工程能力は安定したものとなる。

\section{4. デバイス実装}

われわれが開発したVOA では MEMS を直流電圧でアナ ログ制御するため，電圧を印加した際にミラーが一定の角 度で静止する安定性が必要とされる。デバイスの動作を不 安定にする要素としては電気的なドリフトが主で，これは デバイス性能だけでなく実装技術によるところも大きい。

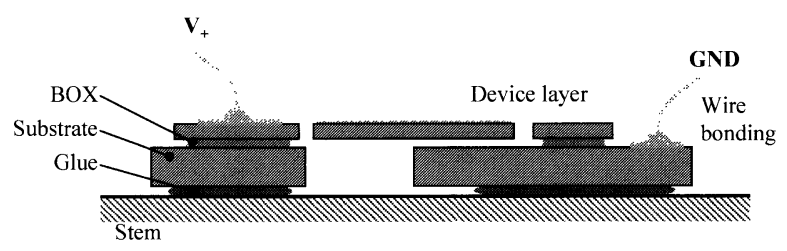

(a)

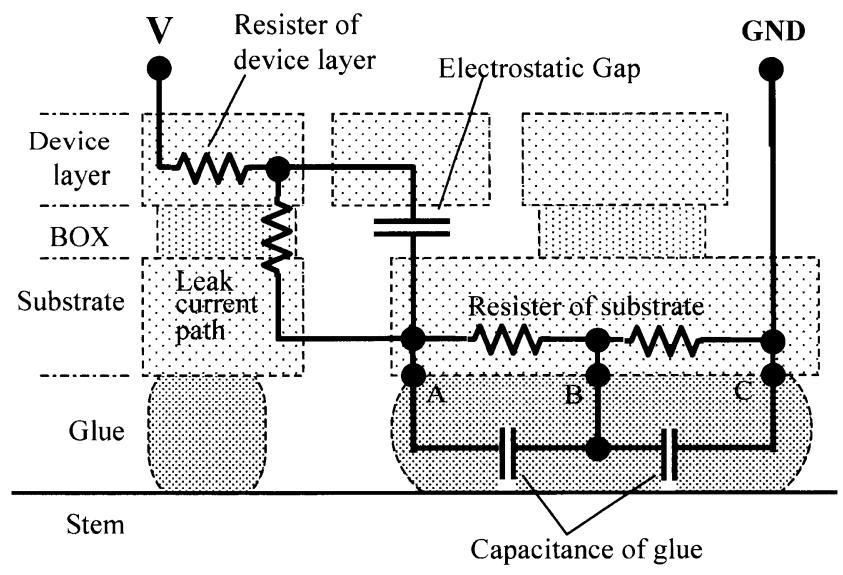

(b)

Fig. 6 Mounting of ASP-type tilt mirror (a) Schematic diagram of mounting, (b) Equivalent circuit model

そこで，本項ではASP型 MEMSの安定性に着目した実装 技術について述べる。

Fig. 6(a)に本開発での MEMS の実装形態を示す。上記の ASP 型MEMS 金属ステム上に接着剤で固定している。強 度を考えた場合ははんだ等による強固な固定が望ましいが， 実装時の応力による特性変動や作業性を考慮して接着剤で の固定を選択した。VOAの仕様によって最適な接着剤は異 なるが，ここではエポキシ系の絶縁性接着剤を用いた。Fig. 7 のグラフ(a)はこの状態でコンポーネントの安定性を評価 した結果である。長期的な変動に加えて短期的な変化も大 きく不安定な特性を示している。Fig. 6(b)はFig. 6(a)の実装 状態の電気的な振る舞いを概念的な等価回路で示してい る。プラス極からデバイス層，静電ギャップ，支持基板を 通ってGNDへとつながる。上下基板間のリーク電流も実際 には発生するため，静電ギャップに並列に抵抗を設けた。 また，ASP型では支持基板全体が下部電極となるため，接 着剂層との界面で帯電する可能性がある。等価回路ではこ れを支持基板抵抗に並列に設けられたコンデンサで表記し た。上述の不安定な状態は，この支持基板と接着剤の界面 の作用で発生している可能性が高く, 帯電およびその不安 定さが主要因と考えている。また，この現象は発生率も不 安定で, 同一ロットのものでも発生の有無や程度に差があ る。経時変化も大きく，作製直後に発生していない場合で も後に発生するケースもある。

本開発ではチップの裏面に金属膜を形成することでこの 現象の改善を試みた。具体的にはチップ裏面に $\mathrm{Cr} / \mathrm{Au}$ をそ 


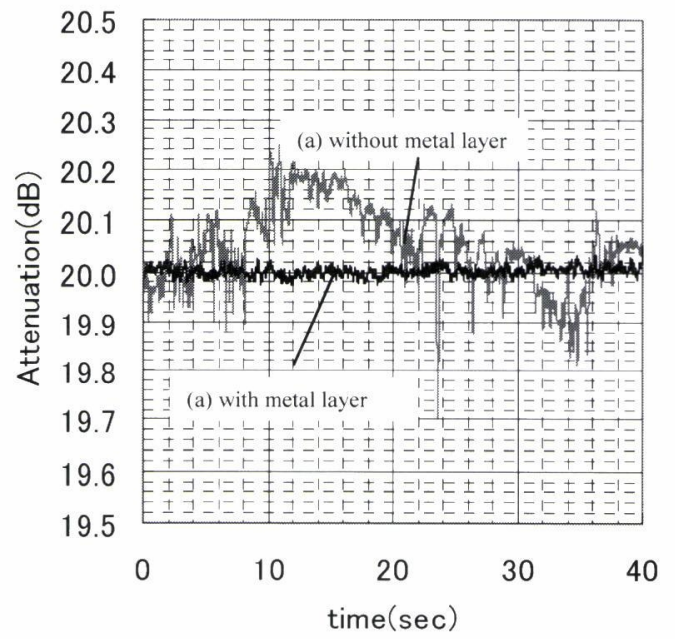

Fig. 7 Stability of the device

れぞれ $50 / 500 \AA$ 蒸着して導電性の高い層を接着剤と下部電 極の間に形成した。この導電膜の効果を等価回路で見ると Fig. 6(b)の A, B, C端をすべて短絡したことと同等になり， 支持基板抵抗に並列なコンデンサは無視できる回路となる。 Fig. 7 のグラフ(b)が改善後の結果であり, 安定度が大幅に 改善されていることがわかる。Cr/Auを形成した場合には 信頼性試験後でも安定性の劣化は見られなかった。

SOI ウエ八の抵抗率は上部基板および支持基板とも 1 10 $\Omega \mathrm{cm}$ 程度である。ASP型ではプルインの際に上下の 電極が接触するため基板抵抗を大きく設定して電極間の短 絡を防止した。低抵抗の基板を用いることでも帯電をある 程度減少させることはできるが，支持基板裏面への導電膜 の形成は基板特性と実装部分を完全に独立させる点で理想 的な対策と考えられる。

\section{VOAの作製結果}

Fig. 8 に試作したVOAの外観写真を示す。外形寸法は $\phi 5.6 \times 23 \mathrm{~mm}$ で従来型のステッピングモータと分布型フィ ルタを用いた VOA と比較すると，体積としては $1 / 27$ となる (同社比)。Fig. 9 に試作したVOA の電圧一減衰特性を示す。 目標とした $30 \mathrm{~dB}$ の減衰量だけでなくシャッター機能をま かなえる $45 \mathrm{~dB}$ の減衰量まで確保できていることがわかる。 電圧一減衰特性は光学系の初期調整を变えることで, 電圧 の上昇に伴って減衰量が増加するタイプ（ブライトモード） と無バイアス状態で最大減衰量を示し電圧の上昇に伴って 減衰量が減少するタイプ（ダークモード）を構成すること ができる。ブライトモードは減衰量の低い状態での特性を 重視する場合に有効であり，またダークモードはシステム への電圧供給が途絶えた際に光が遮断されるような構成が 望まれる場合に有効となる。またダークモードは電圧一減 衰量曲線の傾きがブライトモードと比較して緩やかになる。 Table 1 に試作した MEMS-VOA の諸特性をまとめる。挿入 損失 $0.8 \mathrm{~dB}$ 以下, PDL $0.2 \mathrm{~dB}$ 以下と良好な光学特性が得ら

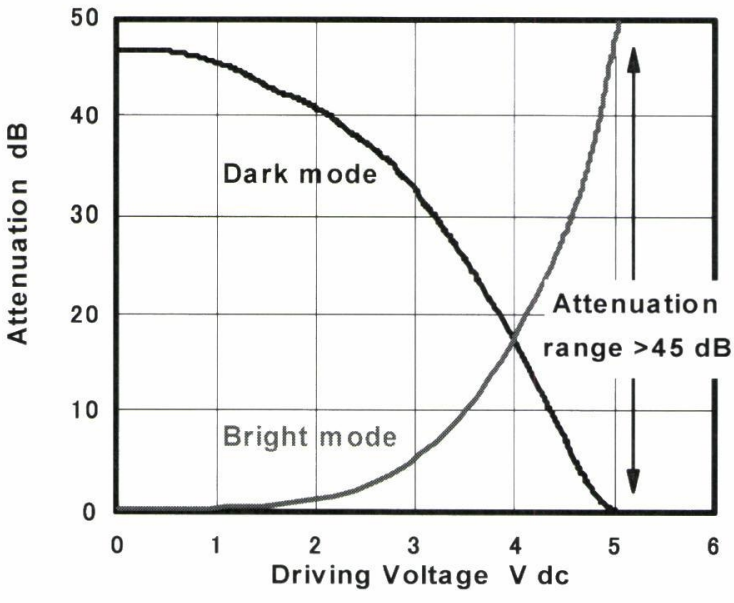

Fig. 8 Optical attenuation versus driving voltage

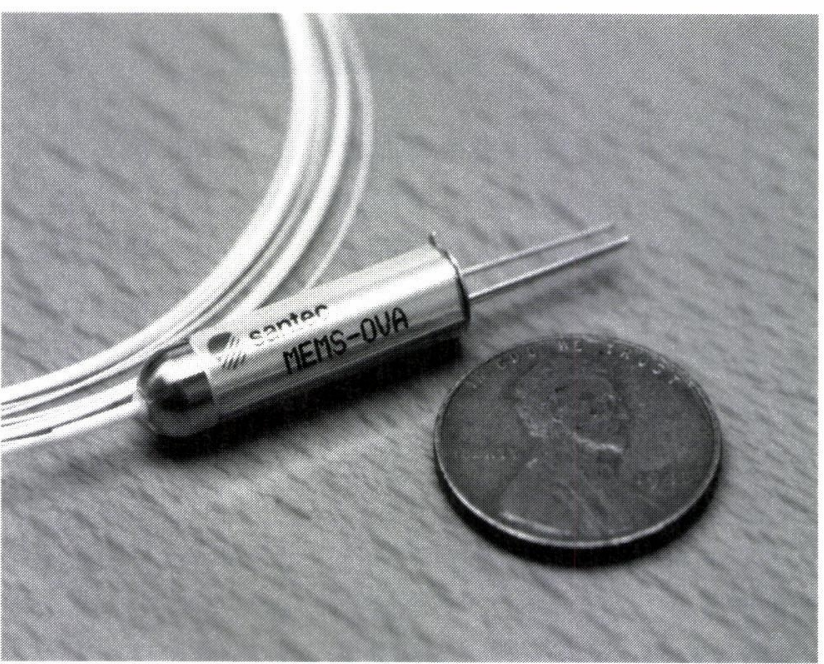

Fig. 9 Photograph of assembled VOA device

Table 1. Specifications of MEMS-VOA

\begin{tabular}{l|c|c}
\hline \multicolumn{1}{c|}{ Parameter } & Value & Note \\
\hline Insertion loss & $<0.8 \mathrm{~dB}$ & \\
Attenuation range & $>45 \mathrm{~dB}$ & \\
Polarization dependent loss & $<0.2 \mathrm{~dB}$ & @20 dB Attenuantion \\
Polarization mode dispersion & $<0.1 \mathrm{ps}$ & \\
Response time & $<5 \mathrm{msec}$ & \\
Driving voltage & $<5 \mathrm{~V}$ & \\
Electrical power consumption & $<10 \mu \mathrm{W}$ & \\
\hline
\end{tabular}

れている。また, 安定性についても実力値として $0.05 \mathrm{~dB}$ 以 下の変動量に収まっている。

\section{6. まとめ}

ASP型チルトミラーMEMSを用いて小型低電圧駆動の VOAを開発した。体積は従来のステッピングモー夕と分布 型フィルタを用いたVOAの 1/27（同社比），可変領域につ いても $45 \mathrm{~dB}$ という大きなダイナミックレンジを実現した。 その他の光学特性についても, 挿入損失 $0.8 \mathrm{~dB}$ 以下, PDL0.2 dB 以下と実使用上十分なレベルを確保した。実装 とデバイス動作の安定性の関係についても考察を進め, 導 
電性の膜をデバイスの裏面に形成することで抜本的な対策

を施した。

また，ASP型MEMS を採用することでSOIを用いたバル クマイクロマシニングによる作製を可能にし工程を大幅に 短縮した。MEMSの設計においては，初期検討段階から量 産時の歩留まりを考慮して設計に取り組み，量産立ち上げ 直後でも $100 \%$ 近い歩留まりを確保した。また, 機能の実 現だけでなく構造, 製造工程ともにシンプルな MEMSを開 発し，その結果，開発着手から約 6 ヶ月で実用レベルのサ ンプルの実現に至った。

(2006.4.10.-受理)

\section{文献}

1) P. F. Van Kessel, L. J. Hornbeck, R. E. Meier and M. R. Dou- glass: "A MEMES-Based Projection Display," Proceedings of the IEEE, Vol. 86, No. 8, pp. 1687-1704, August 1998

2) D. Neilson, V. Aksyuk, S. Arney, N. Basavanhally, K. Bhalla, D. Bishop, B. Boie, C. Bolle, J. Gates, A. Gottlieb, J. Hickey, N. Jackman, P. Kolodner, S. Korotky, B. Mikkelsen, F. Pardo, G. Raybon, R. Ruel, R. Scotti, T. Van Blarcum, L. Zhang and C. Giles: "Fully Provisioned $112 \times 112$ Micro-Mechanical Optical Crossconnect with $35.8 \mathrm{~Tb} / \mathrm{s}$ Demonstrated Capacity," Optical Fiber Conference (OFC 2000), Mar. 7-9, 2000, Boltimore MD, USA, PD12-1

3) K. Isamoto, K. Kato, A. Morosawa, C. Chong, H. Fujita and H. Toshiyoshi: "A 5-V Operated MEMS Variable Optical Attenuator by SOI Bulk Micromachining," IEEE J. Select. Topics Quantum Electron., Vol. 10, pp. 570-578, May-June 2004 